\title{
THE LIABILITY OF NONEMPLOYER TORTFEASORS UNDER STATE WORKMEN'S COMPENSATION STATUTES: A CHOICE-OF-LAW PROBLEM
}

\author{
ALAN W. FORD $\dagger$
}

\section{INTRODUCTION}

GeNERALLy speaking, the various state workmen's compensation statutes establish a scheme of social insurance against the economic consequences of industrial accidents. Typically, these statutes provide that, regardless of fault, employers must provide compensation for accidental injuries in accordance with statutorily established scales and that, in return, employers are relieved of common-law tort or wrongful-death liability arising out of the employment relationship. ${ }^{1}$ Since the enactment of the first American compensation laws, however, the states have pursued dissimilar policies in distinguishing fully liable third-party tortfeasors from employers whose liability to employees is limited by the compensation acts. Moreover, some states allow the employee or his administrator to receive compensation payments from the employer and to sue a third-party tortfeasor as well, while other states lodge the exclusive right to initiate such a suit in the insurer who actually made the compensation payments. $^{2}$ Consequently, if an employee crosses a state boundary in connection with his employment and then suffers injury or death for which compensation is subsequently awarded, the contrasting attitudes of the several states may create difficult choice-of-law questions in a third-party tort suit. These questions and the kinds of solutions that courts have fashioned are illustrated by the cases described in the following paragraphs.

Biddy v. Blue Bird Air Service. ${ }^{3}$ Ralph Biddy, a resident of Michigan and an employee of a Michigan corporation, was killed in an airplane crash in Illinois. After his dependents had received an award under the Michigan workmen's compensation act, Biddy's administratrix commenced a wrongful-death action in Illinois against the operators of the airplane. Defendants claimed that, under both the Michigan and Illinois compensation acts, the cause of action for wrongful death belonged solely to the plaintiff's compensation insurer. ${ }^{4}$ Having lost below, the defendants argued on appeal that the trial court's refusal to permit proof of the Michigan law was a violation of the federal Constitution's full faith and credit clause. Agreeing with this contention, the

$\dagger$ Member of the California Bar.

1. See, 1 Sch neider, Workmen's Comprensation 1-17 (1941).

2. See notes $20-28$ infra and accompanying text.

3. 374 II1. 506, 30 N.E.2d 14 (1940).

4. "Insurer," as used in this Article, designates the person who pays or who is obligated to pay statutory workmen's compensation to an injured employee. 
Supreme Court of Illinois held that the Michigan act-providing that acceptance $^{5}$ of compensation ${ }^{6}$ by an injured employee or his dependents gave the insurer an exclusive right to enforce the liability of the third party ${ }^{7}$-was within the "legislative jurisdiction"8 of the State of Michigan, and that the courts of Illinois must therefore accord it full faith and credit.

Personius v. Asbury Transportation Co.9 Alleging defendant's negligence, Personius, a bus driver, commenced a tort action ${ }^{10}$ in Oregon for injuries resulting from a collision in that state between his bus and the defendant's truck. Prior to commencing the suit, Personius had accepted an award ( $\$ 44.60)$ under the workmen's compensation act of Idaho, the state where he resided and where his employment contract had been made. The Idaho statute provided that if an employee accepted a compensation award, the insurer paying the award would be subrogated to the employee's rights against the third-party tortfeasor. Accordingly, defendant argued that Personius would have been nonsuited had he brought the action in Idaho, and that a failure by the Oregon courts to sustain the defendant's plea in abatement would thus constitute a denial of full faith and credit to the Idaho act. Nonetheless, the Supreme Court of Oregon affirmed Personius' judgment for $\$ 10,000$ on the ground that, since the cause of action was based on the defendant's tortious conduct in Oregon, the critical issue was whether a remedy for that tort existed under the laws of Oregon. The court acknowledged that Idaho could prohibit Personius from suing the defendant in its courts, but ruled that such a prohibition could have

5. Some cases have distinguished between situations in which a formal award has been made and those in which compensation has been accepted in the absence of an award. The distinction is not, however, material to the main discussion in this Article and is, therefore, ignored. See the cases cited by WRIGHT, SUbrogation UnDER WORKMEN's Compensation ACts 24 nn.7 \& 8 (1948).

6. "Compensation," as used in this Article, denotes not only the compensation payments made or awarded to the employee or his dependents, but also the medical, hospital, and funeral expenses paid by the insurer and costs of litigation where included by state law.

7. As used in this Article, a "third party" is a person other than one whose common-law or wrongful-death liabilities to an injured or dead employee have been abolished or limited by a workmen's compensation law. Definitions of the term "third party" vary from state to state. See note 17 infra.

8. The phrase used by the court reflects the basic assumption or theory of the Restatement of the Conflict of Laws, that, with respect to a particular set of facts, a particular state is assigned the power to create legal interests that must be recognized and enforced in other states. For criticism of this theory, see Cook, The Logical and Legal Bases of the Conflict of Laws chs. 1-3 (Harvard Studies in the Conflict of Laws Vol. 5, 1942); Lorenzen, Territoriality, Public Policy, and the Conflict of Lazes, 33 YALE L.J. 736 (1924); Lorenzen and Heilman, The Restatement of the Confict of Lazws, 83 U. PA. L. REv. 555 (1935); Yntema, The Hornbook Method and the Conflict of Laws, 37 YALE L.J. 468 (1928).

9. 152 Ore. 286,53 P.2d 1065 (1936).

10. The phrase "tort action" is used in this Article to designate both common-law negligence and statutory wrongful-death actions. 
no extraterritorial effect in Oregon. Citing Supreme Court authority ${ }^{11}$ for the proposition that the full faith and credit clause does not prohibit a state court from applying its own law in an action for the redress of an injury occurring within the forum state, the Oregon tribunal concluded that it was not required to enforce the policy expressed in the Idaho statute. ${ }^{12}$

Liberty Mutual Insurance Co. v. Goode Construction Co. ${ }^{13}$ Budano, who resided and was employed in the District of Columbia, was injured while working on a construction project in Virginia on which his District of Columbia employer was a subcontractor. After accepting compensation from the subcontractor under District of Columbia law, Budano, joined by the compensation insurer and alleging that his injury was caused by the negligence of the general contractor's employees, brought a third-party tort action in Virginia against the general contractor. Defendant urged that Virginia law was controlling and that, under it, a general contractor is an employer, not a third party liable in tort to the employees of his subcontractors. The court rejected this argument on the theory that the compensation law of the District of Columbia, under which defendant was a "third party," was incorporated in Budano's employment contract, ${ }^{14}$ and was therefore controlling.

Standard Oil Co.v. Lyons, ${ }^{15}$ Raiche v. Standard Oil Co. ${ }^{16}$ Lyons and Raiche, both residents of Iowa, were killed by the explosion of a chemical waterproofing which they were applying inside a large metal tank being built in Illinois. The dependents of both workers received workmen's compensation awards under the Iowa act. Thereafter, their administrators, claiming that the manufacturer was negligent in selling the chemical without notice of its highly volatile character, brought separate wrongful-death actions against the manufacturer of the waterproofing in a federal court in Iowa. The insurer joined in both actions. In both cases, the court reasoned that the controlling law was the compensation act of the state in which decedent had made his contract of employment. In the Lyons case, the court then found that because the offer of employment had been spoken in Illinois and accepted in Iowa (via telephone), the contract had been made in Iowa. Under the Iowa compensation act, Lyons' administrator could properly maintain the wrongful death action. In the Raiche case, on the other hand, the court found that decedent had been in Illinois when he accepted the offer of employment, and that his contract thus had been made in Illinois. Since, under the law of Illinois, the acceptance of compen-

11. Alaska Packers Ass'n v. Industrial Acc. Comm'n, 294 U.S. 532 (1935).

12. IDAmo Code ANn. $\S 43-1004$ (1932) (at the time of the Personius case), currently IDAHO CODE ANN. § 72-204 (1947).

13. 97 F. Supp. 316 (E.D. Va. 1951).

14. Id. at 317. For other discussions of this theory, see Magee v. McNany, 10 F.R.D. 5, 10 (W.D. Pa. 1950) ; Reutenik v. Gibson Packing Co., 132 Wash. 108, 122, 231 Pac. 773, 777 (1924); Anderson v. Miller Scrap Iron Co., 176 Wis. 521, 524, 182 N.W. 852, 853 (1922). See also Betts v. Southern Ry., 71 F.2d 787, 789 (4th Cir. 1934); Alexander v. Creel, 54 F. Supp. 652, 658 (E.D. Mich. 1944).

15. 130 F.2d 965 (8th Cir. 1942).

16. 137 F.2d 446 (8th Cir. 1943). 
sation had the effect of vesting the tort cause of action exclusively in the insurer, the court dismissed the administrator's action-despite the fact that compensation had been paid to Raiche's dependents pursuant to the Iowa, not the Illinois, act.

\section{Choice-of-Law Problems}

The foregoing cases typify rapidly increasing litigation which often presents two difficult choice-of-law problems. The first is to determine the applicable compensation statute for deciding whether the defendant is a third party. The second, to decide which state's act establishes whether the employee, his administrator, or his insurer may properly assert the third-party tort claim. Underlying both problems is the further question-does the Constitution require any particular choice of law? These questions arise because definitions of "third party" vary greatly from state to state, ${ }^{17}$ and because compensation acts differ in delimiting the respective rights of the injured employee and the compensation insurer to maintain a tort action against a third-party tortfeasor once the employee has accepted statutory compensation for his injury.

These various third-party provisions were enacted not for the benefit of the third party, ${ }^{18}$ but to protect the insurer's right to reimbursement and to prevent the employee from obtaining the unjust enrichment of a double recovery -compensation plus tort damages-for the same injury. ${ }^{19}$ Some statutes ${ }^{20}$

17. In some states the immediate employer alone is exempt from the third-party classification. See, e.g., ARK. Const. art. 5, $\$ 32$, construed in Young v. G. L. Tariton, Contractor, Inc., 204 Ark. 283, 288, 162 S.W.2d 477, 479 (1942), and Anderson v. Sanderson \& Porter, 146 F.2d 58, 62 (\&th Cir. 1945). Some states exclude fellow employees from the category "third party" and thus from tort and wrongful-death liability. See, c.g., Colo. Rev. Stat. ANn. \$ \$1-13-8 (1953); Ill. Rev. Stat. ch. 48, \$138.5(b) (1953). Other states limit the liability of all employers who are covered by the local compensation act to the amounts specified in that act. See, e.g., ArA. Cope tit. 26, $\$ 31.1$ (1940); Minn. Stat. $\$ 176.031$ (1949). For a general discussion, see 2 Larson, Worknen's Compensation $\$$ 72.00-.70 (1952); 3 Schneider, Workmen's Coarpensatron $\$ 842$ (perm. ed. 1943); Wright, Subrogation Under Workmen's Compensatron ACts ch. 4 (1948); Riesenfeld, Contenporary Trends in Compensation for Industrial Accidents Herc and Abroad, 42 CalIF. L. Rev. 531, 563-657 (1954).

18. A few states do benefit the third party, if he is an employer operating under the local compensation act, by limiting the recovery from him to the compensation specified in the local act. See the Alabama and Minnesota statutes cited note 17 supra; 3 Schneider, WorkMren's CoMpensation \$ 836, at 196-97 (Supp. 1958); cf. note 21. infra (third paragraph).

19. Jay v. Chicago Bridgè \& Iron Co., 150 F.2d 247, 249 (9th Cir. 1945); Magee v. MeNany, 10 F.R.D. 5, 13 (W.D. Pa. 1950) ; New York Cent. R.R. v. Milhiser, 231 Ind. 180, 187, 106 N.E.2d 453, 457 (1952) ; Kandelin v. Lee Moor Contracting Co., 37 N.M. 479, 484, 24 P.2d 731, 734 (1933), quoting from McArthur v. Dutee W. Flint Oil Co., 50 R.I. 226, 231, 146 At1. 484, 487 (1929) ; Reutenik v. Gibson Packing Co., 132 Wash. 108, 123, 231 Pac. 773, 778 (1924); Bernard v. Jennings, 209 Wis. 116, 120, 244 N.W. 589, 591 (1932).

20. The textual description that follows does not purport to be a complete and ac- 
provide that the employee's acceptance of compensation subrogates ${ }^{21}$ the person who has paid or is responsible for paying the compensation to the employee's rights against the third party. ${ }^{22}$ Under these statutes, the assignee or

curate classification of the various statutes; instead, it is intended to note only the principal types which have been involved in the conflicts cases discussed in this Article.

21. Alaska Comp. Laws Ann. \$ 43-3-30 (1949); Del. Code Ann. tit. 19, $\$ 2363$ (Supp. 1956) (if employee or his representative fails to commence action within 260 days after date of injury, employer or insurance carrier may enforce liability in name of employee); Fla. Stat. ANN. $\$ 440.39$ (1952); HawaII Rev. LAws $\$ 97-10$ (1955) (employer subrogated nine months after date of injury, if employee fails to sue third party); Idaho Code ANn. \$ 72-204 (1947); Mle. Rev. Stat. AnN. ch. 31, § 25 (1954); Md. Ann. Code art. 101, \&58 (1957); Mass. Ans. Laws ch. 152, $\$ 15$ (1957); Мrch. Stat. ANN. $\$ 17.189$ (Supp. 1957) (one year after injury, employer may enforce rights of employee if employee fails to do so); MinN. Stat. ANN. $\$ 176.061$ (Supp. 1957) (subrogation limited to cases in which the third party is insured or self-insured for workmen's compensation purposes); Mo. Rev. STAT. § 287.150 (Supp. 1956) ; NEv. Rev. Stat. § 616.560 (1956); N.C. Gen. Stat. Ann. § 97-10 (1950); PA. Stat. Ann. tit. 77, § 671 (Supp. 1957); P.R. LAws ANN. tit. 11, 332 (1954); S.D. CoDE $\S 64.0301$ (1939) ; Tex. Rev. Civ. Stat. Ann. art. 8307, § 6a (1956) ; Utam Code ANn. § 35-1-62 (1953); Vт. Stat. § 8078 (1947).

The following statutes are worded in terms of an assignment of the employee's rights to his insurer: ArIz. Cone $\$ 56-949$ (1939); Colo. Rev. STAt. AnN. $\$$ \$1-13-8 (1953); N.M. Star. Anv. § 59-10-25 (1953); OKLA. Stat. tit. 85, \& 44 (1951) (exclusive of actions by employee's dependents for wrongful death); OrE. REv. STAT. $\$ 656.320$ (1957); S.C. CODE § 72-124 (1952); VA. CODE ANN. \$ 65-38 (1950); Longshoremen's and Harborworkers' Compensation Act, 44 Stat. 1440 (1927), as amended, 33 U.S.C. $\S 933$ (1952).

The Illinois statute contained a provision that if a third party were bound by the act, acceptance of compensation would operate as an assignment of the employee's entire interest in the tort cause of action to his insurer, who could recover no more than the amount of compensation paid. Ill. Rev. Stat. ch. 48, § 166 (1947). The Supreme Court of Illinois in Grasse v. Dealer's Transp. Co., 412 Ill. 179, 106 N.E.2d 124, cert. denied, 344 U.S. 837 (1952), held that provision to be in conflict with the equal protection and due process clauses of the federal constitution as an arbitrary classification. This assignment section was also held to violate several provisions of the Illinois constitution. See critical note, Illinois Worknen's Compensation: Recovery of Damages From Third Party Employer Tortfeasors, 48 Nw. U.L. REv. 514 (1953), in which the Grasse case is read narrowly as affecting only actions by compulsorily, rather than electively, bound employees against compulsorily bound employers. A broader construction was accepted in a subsequent case, Geneva Constr. Co. v. Martin Transfer \& Storage Co., 351 IIl. App. 289, 114 N.E.2d 906 (1953), in which the distinction between compulsorily and electively bound employees and employers is not mentioned. This case also established that, in Illinois, insurers have a common-law right to subrogation for the amount of compensation paid, in the' absence of a statutory provision therefor. On the latter point, see note 77 infra.

22. Some of the statutes cited in note 21 supra, as well as the earlier legislation from which they were derived, required an injured employee to make a complicated and often inequitable election either to seek compensation or to pursue the third party; he could not do both. Most states have now abandoned this election system, and courts and legislatures have made its operation less harsh in the states where it still remains. See Riesenfeld, supra note 17, at 569 ; statutes cited notes 23 and 24 , infra. 
subrogee can proceed directly against the third party, ${ }^{23}$ the employee being entitled to any recovery in excess ${ }^{24}$ of the compensation award. Other statutes permit the employee to maintain a tort action against the third party, but provide that the insurer has a lien on the judgment recovered for the amount of the compensation award, or is entitled to reimbursement for that amount from the proceeds of the action. ${ }^{25}$ Several statutes also provide that if the employee does not bring his action against the third party within a specified time (usually six months or one year), his insurer may do so. ${ }^{26}$ In only two states are the compensation acts silent as to the maintenance of tort actions against third parties. ${ }^{27}$ In both, courts have held that the employee may retain the compensation award and the proceeds of his tort recovery without reimbursing his insurer for the compensation benefits received. ${ }^{28}$

The administration of these third-party provisions is sufficiently difficult in cases in which all of the relevant events occurred within one state. A case involving contacts with two or more states presents added complications, however, for the compensation laws do not include provisions designed to resolve a conflict of laws. The purpose of this article is to discuss the problems created by multi-state fact situations and to evaluate the choice-of-law rules that courts apply in resolving those problems. ${ }^{29}$

23. See the statutes of Florida, Maine, Maryland, Massachusetts, North Carolina, South Carolina and Puerto Rico cited note 21 supra.

24. This provision is common to all of the statutes cited in note 21 supra, the only exception being of the kind cited in note 18 supra.

25. Ala. Code tit. 26, § 312 (Supp. 1955); Ark. Const. art. V, § 32; Ark. Stat. ANN. § 81-1340 (Supp. 1957) ; Cal. Lab. Code \$§ 3852, 3856; Conn. Gen. Stat. § 7425 (1949); Ga. Code AnN. § 114-403 (Supp. 1955); Ill. Ann. Stat. ch. 48, § 172.40 (Smith-Hurd Supp. 1957); Ind. Stat. Ann. \$ 40-1213 (Supp. 1955) ; Iowa Code AnN. $\$ \$ 5.22$ (1946) ; Kan. Gen. Stat. Ann. \$ 44-504 (Supp. 1957) ; Ky. Rev. Stat. Ann. \$ 342.055 (1955) ; La. Rev. Stat. Ann. \$ 23-1101 (1950) ; Minn. Stat. Ann. \$ 176.061 (Supp. 1957) ; Miss. Code Ann. § 6998-36 (1952); Mont. Rev. Code Ann. \$ 92-204 (1947) (lien for lesser of one-half compensation paid or damages recovered) ; NEB. REv. Stat. § 48-11S (1952) ; N.J. Rev. Stat. \& 34:15-40 (Supp. 1957) ; N.Y. Workmen's Comp. LAw $\S 29$; N.D. Rev. CoDe $\$ 65.0109$ (Supp. 1949) (plaintiff a trustee for insurer); OrLA. Stat. ANN, tit. 85, $\$ 44$ (1951) (no subrogation in cases where an employee's degendents are asserting a cause of action for wrongful death) ; R.I. GEN. Laws Ann. ch. 28, \& 35-58 (1956); Tenn. Code Ann. \$ 50-914 (1955); Wis. Stat. $\S 102.29$ (1953). See also Federal Employee's Compensation Act, 39 Stat. 747 (1916), as amended, 5 U.S.C. $\$ \$ 776,777$ (1952) (employee can accept compensation and sue the third party unless the Bureau of Employees' Compensation orders an assignment of his tort cause of action).

26. See statutes of Alabama, Illinois, Indiana, Iowa, Kansas, Montana, New Jersey and New York cited note 25 supra.

27. These states are Ohio and West Virginia. See Trumbull Cliffs Fumace Co. v. Shackovsky, 27 Ohio App. 522, 161 N.E. 238 (1923) ; Merrill v. Marietta Torpedo Co., 79 W. Va. 669, 92 S.E. 112 (1917).

28. Crab Orchard Improvement Co. v. Chesapeake \& O. Ry., 33 F. Supp. 580 (S.D. W. Va.), aff'd, 115 F.2d 277 (4th Cir. 1940); Truscon Steel Co. v. Trumbull Cliffs Furnace Co., 120 Ohio St. 394, 166 N.E. 368 (1929) ; George v. City of Youngstown, 139 Ohio St. 591, 41 N.E.2d 567 (1942).

29. The difficulties involved in this attempt have been noted by several scholars. 


\section{Constitutional Full Faite and Credit in the Choice of Statutory LAW}

It has long been uncertain whether the full faith and credit clause requires a particular choice of law to determine, first, whether a given defendant is a third party and, second, whether the employee-plaintiff may bring a third-party tort action, ${ }^{30}$ for courts have given conflicting interpretations of that clause in this context. ${ }^{31}$ In 1955, however, the Supreme Court in deciding Carroll $v$.

See, for example, Horovitz, Workmen's Confensation 342 (1944) ; Riesenfeld \& Maxwell, Modern Social Legislation $439-40$ n.14 (1950); Dwan, Workmen's Compensation and the Conflict of Laws, 11 MINN. L. REv. 329, 349-52 (1927) ; Dwan, Workmen's Compensation and the Confict of Laws-the Restatement and Other Recent Developments, 20 MrNN. L. REv. 19, 44 (1935) ("It is difficult if not impossible to formulate many useful generalizations as yet."); Riesenfeld, supra note 17, at 571-78. But cf. 2 Larson, Workmen's Compensation \$\$ 88.22-.23 (1952). See also Wright, SubrogaTION UNDER WORKMEN's CONIPENSATION ACTS 15-17 (1948).

30. As is insufficiently realized, giving full faith and credit to statutes elevates choiceof-law rules to constitutional dignity. In Wells v. Simonds Abrasive Co., 345 U.S. 514, 516 (1953), for example, the Supreme Court said: "The Full Faith and Credit Clause does not compel a State to adopt any particular set of rules of conflict of laws; it merely sets certain minimum requirements which each state must observe when asked to apply the law of a sister State." The following statement of Justice Black, writing for the Court in Hughes v. Fetter, 341 U.S. 609, 611 (1951), reflects a more accurate awareness of the choice-of-law problem: "[I]t is for this court to choose . . . between the competing public policies involved." See also Justice Jackson's concurrence in First Nat'l Bank v. United Air Lines, 342 U.S. 396, 401. (1952), and Jackson, Full Faith and Credit-The Lazyer's Clanse of the Constitution, 45 Colum. L. Rev. 1, 16 (1945).

Despite the clear statements by Justices Black and Jackson, it was said that in Hughes v. Fetter, supra, (and similar cases) the Supreme Court "was not concerned with the impact of full faith and credit upon the complexities of choice of law" because "Wisconsin was not here trying to apply its own law to the transaction ...." Reese, Full Faith and Credit to Statutes: The Defense of Public Policy, 19 U. CEI. L. REv. 339, 345 (1952). Although Hughes v. Fetter involved the narrow question whether Wisconsin could close the doors of its courts to a cause of action based on the Illinois wrongful death statute, the court recognized that if this question were answered in the negative (as it was) Wisconsin would have a "constitutional obligation to enforce the rights and duties validly created under the laws of other states. ..."341 U.S. at 611. Thus a choice of law is implicit in the decision, for unless it is assumed that the law of the place of the wrong is determinative of the existence of a cause of action, the narrow question presented to the Court could not arise. The same choice of law assumption is made in First Nat'l Bank v. United Air Lines, supra at 397-98.

For a clear exposition of the argument that full faith and credit involves a constitutional choice of law, see Rheinstein, The Constitutional Bases of Jurisdiction, $22 \mathrm{U}$. CHI. L. REv. 775, 788-89 (1955).

31. Full faith and credit relied upon as a basis of decision: Bradford Elee. Light Co. v. Clapper, 286 U.S. 145 (1932); Ohlhaver v. Narron, 195 F.2d 676, 679 (4th Cir. 1952) ; Alexander v. Creel, 54 F. Supp. 652, 656-58 (E.D. Mich. 1944) ; Biddy v. Blue Bird Air Serv., 374 I11. 506, 511-12, 30 N.E.2d 14, 19 (1940); Smith v. Clavey Ravinia Nurseries, Inc., 329 I1l. App. 548, 560, 69 N.E.2d 921, 927 (1946). But see discussion of Clapper in note 47 infra. See also Cole v. Industrial Comm'n, 353 Ill. 415,187 N.E. 520 (1933).

Full faith and credit rejected as basis of decision: Jonathan Woodner Co. v. Mather, 
Lanza ${ }^{32}$ held that the Constitution does not compel any particular choice among alternative compensation acts in characterizing defendants as third parties.

Carroll $v$. Lanza was a tort action brought in a federal court in Arkansas by a subcontractor's employee. ${ }^{33}$ Plaintiff sought redress from a general contractor for injuries received in the course of employment in Arkansas. The plaintiff had been hired in Missouri, the state in which he and the subcontractor resided. The subcontractor carried insurance for his employees under both the Missouri and Arkansas acts, and the plaintiff, before commencing the tort action, had received compensation under both statutes, although a final award had not been made under either. The trial court rejected the contention ${ }^{34}$ that it was obliged to give full faith and credit to the Missouri compensation act, which relieved general contractors of common-law liability for injuries to the employees of subcontractors. ${ }^{35}$ Under the Arkansas act, which the trial court held to be applicable, the defendant was liable as a third party. ${ }^{36}$ The Eighth Circuit reversed ${ }^{37}$ on the ground that Magnolia Petroleum Co. $v$. Hunt ${ }^{38}$ required a court sitting in Arkansas to give full faith and credit to the Missouri compensation act. The Supreme Court then reversed the court of appeals. ${ }^{39}$

210 F.2d 868,872 (D.C. Cir. 1954) ; Bagnel v. Springfield Sand \& Tile Co., 144 F.2d 65, 72 (1st Cir. 1944) ; Magee v. MeNany, 10 F.R.D. 5, 12-13 (W.D. Pa. 1950) ; Miller v. Yellow Cab Co., 30S I11. App. 217, 227-33, 31 N.E.2d 406, 410-12 (1941) (citing, inter alia, Biddy v. Blue Bird Air Serv., supra, and Personius v. Asbury Transp. Co., 152 Ore. 286, 310-11, 53 P.2d 1065, 1075 (1936)).

32. 349 U.S. 408 (1955).

33. The federal court had jurisdiction by virtue of diversity of citizenship; the defendant-Lanza-was a resident of Louisiana. Carroll v. Lanza, 116 F. Supp. 491, 494 (W.D. Ark. 1953).

34. Id. at 501-03.

35. Mo. Ann. Stat. $\$ 287.040$ (1952) ; Bunner v. Patti, 343 Mo. 274, 283, 121 S.W. $2 \mathrm{~d} 153,156-57$ (1938).

36. Arr. Stat. Ann. $\S 81-1340$ (Supp. 1957) ; Baldwin Co. v. Maner, 224 Ark. 348, 273 S.W.2d 28 (1.954).

37. 216 F.2d 80 S (Sth Cir. 1954).

38. 320 U.S. 430 (1943).

39. 349 U.S. 408 (1955). That neither the majority of the Supreme Court nor the dissenting Justices (Frankfurter, Harlan and Burton) found any merit in the court of appeals reliance on the Magnolia case is noteworthy. The majority concluded that Magnolia was not in point because the plaintiff in that case had obtained a final award of compensation in the state of injury before returning to the state of his residence to commence a second action. The Court made no mention of the fact that the second action was not in tort but was a claim for additional compensation under the statute of the employee's home state. In connection with its discussion of Pacific Employers Ins. Co. v. Industrial Acc. Comm'n, 306 U.S. 493 (1939), however, the Court did assert that the fact that Carroll $v$. Lanza was a common-law tort action rather than a claim for statutory compensation "is not in our judgment a material difference." 349 U.S. at 412. A1though this statement in the future properly might be limited so that the "balancing of interests" doctrine of full faith and credit to statutes is equally applicable to actions for tort or for compensation, in light of the Court's ground for distinguishing the Magnolia case the quoted declaration nevertheless might be interpreted to mean that where an employee has received a final compensation award under the statutes of one state, a 
In an opinion by Justice Douglas, the Court applied the "balancing of interests" doctrine of Pacific Employers Insurance Co. v. Industrial Accident Commission." Pacific Employers, the Court said, "teaches that in these personal injury cases the State where the injury occurs need not be a vassal to the home state and allow only that remedy which the home State has marked as the exclusive one. The State of the forum also has interests to serve and protect." 11 Because the state of injury has "large and considerable" interests such as the "problems of medical care and of possible dependents," 42 the Court concluded that Arkansas could refuse to adopt Missouri's policy and could apply its own law "even though in this case Carroll's injury may have cast no burden on her or on her institutions." 43 In so holding, the Court actually extended the Pacific Employers doctrine, since that case, unlike Carroll, involved not a tort action but a claim for statutory compensation. ${ }^{44}$ Thus, the effect of Carroll is to enable the courts of a state in which an injury has occurred to apply the laws of that state in determining whether the injured employee is limited to statutory workmen's compensation or has, in addition, a remedy in tort. By analogy, established construction of the full faith and credit clause ${ }^{45}$ should give the

constitutional mandate requires that those statutes must control any tort action thereafter commenced in any other state. Such a proposition is plainly at variance with the Court's reasoning in Carroll $v$. Lanza. Therefore, it would have been preferable to have distinguished the Magnolia case on the ground that the employee's second action was for statutory compensation and not for tort recovery, and that his rights to compensation had become res judicata by the earlier final compensation award in the state of injury. See Cheatham, Res Judicata and the Full Faith and Credit Clause: Magnolia Petroleum Co. v. Hunt, 44 CoLum. L. Rev. 330, 346-51 (1944).

The constitutional issues involved in Carroll $v$. Lanza have been discussed in several articles: Clark, Work-Injuries and the Constitution: Carroll v. Lanza, 1956 WASH. U.L.Q. 320; Hogan, Constitutional Implications of Workmen's Compensation and Choice of Law, 7 Hastrngs L.J. 268 (1956) ; Langschmidt, Choice of Law in Workmen's Compensation, 24 Tenn. L. Rev. 322 (1956) ; Stone, The Forum's Policy and the Defense of Faith and Credit to Workmen's Compensation Acts, 41. IowA L. REv. 558 (1956).

40. 306 U.S. 493 (1939).

41. 349 U.S. at 412.

42. Id. at 413. Justice Frankfurter in his dissenting opinion disagreed: “. . . the interest of the forum here is solely dependent on the occurrence of the injury within its borders. No rights of Arkansas residents are involved, since none of the parties is an Arkansan; the workman [Carroll] was removed immediately to a Missouri hospital and has, so far as appears, remained in Missouri." Id. at 420. Carroll had, however, received compensation under the Arkansas act. See also note 50 infra.

43. 349 U.S. 412,413 (1955).

44. The Court declared that this "is not in our judgment a material difference." Id. at 412. Cf. Alaska Packers Ass'n v. Industrial Acc. Comm'n, 294 U.S. 532, 541 (1935):

The fact that the contract [of employment] is to be performed elsewhere does not of itself put these incidents beyond reach of the power which a state may constitutionally exercise. [Citations.] While a similar power to control the legal consequences of a tortious act committed elsewhere has been denied, [citations], the liability under workmen's compensation acts is not for a tort. It is imposed as an incident of the employment relationship ....

45. Ibid., holding that the California courts need not give full faith and credit to the workmen's compensation acts of the place of injury (Alaska), but, on the basis of 
courts of a state in which the injured employee's contract of employment was made a similar freedom from constitutional compulsion when a third-party tort action is commenced in that state. ${ }^{46}$

Carroll v. Lanza extends other recent decisions constricting the area of constitutional compulsion for state choice-of-law decisions. ${ }^{47}$ In Pacific Employers, for instance, the Court had given attention to the relative weight of the interests of California and Massachusetts and had emphasized that California, the forum state, attached importance to its policy of affording plaintiff a remedy under local law. ${ }^{48}$ In Carroll, however, the Court necessarily implied that the interests of the injured employee's home state and of the state in which the tort occurred need no longer be balanced in the light of each particular fact situation. ${ }^{49}$ The Court held that the mere occurrence of the injury in Arkansas, without more, was sufficient to give courts sitting in Arkansas complete freedom in making their choice of law. Moreover, the Court stated that this choice-of-law freedom would exist were Arkansas' interests not actually present in any given case ${ }^{\text {s0 }}$ but only inherent in the "kind of situation presented." 51

Carroll v. Lanza suggests that the present Court will continue to narrow the area in which the full faith and credit clause is said to require a particular choice of law. Although the issue was not raised there, the decision supports

the fact that the employment contract had been made in California, could award compensation under the California statutes.

46. This proposition was held in Jonathan Woodner Co. v. Mather, 210 F.2d 868 (D.C. Cir.), cert. denied, 348 U.S. 824 (1954), 67 HARv. L. REV. 1281. The nonconstitutional choice-of-law problem in this case is discussed in the text accompanying note 62 infra.

47. Watson v. Employers Liability Assur. Corp., 348 U.S. 66 (1954); Cardillo v. Liberty Mut. Ins. Co., 330 U.S. 469 (1947); Pacific Employers Ins. Co. v. Industrial Acc. Comm'n, 306 U.S. 493 (1939); Alaska Packers Ass'n v. Industrial Acc. Comm'n, 294 U.S. 532 (1935). By its decision in Carroll $v$. Lanza, the Court has now completely overruled Bradford Elec. Light Co. v. Clapper, 286 U.S. 145 (1932), and discarded what remained of that case after the inroads made earlier in Alaska Packers and Pacific Employers. In Carroll $v$. Lanza, the Court remarked that Pacific Employers "departed, however, from the Clapper decision." 349 U.S. at 412. Compare Justice Stone's concurring opinion in the Clapper case with the opinions he wrote for the Court in the Alaska Packers and Pacific Employers cases.

48. 306 U.S. at 504; see Justice Frankfurter's dissenting opinion in Carroll v. Lanza, 349 U.S. 408,421 n.3 (1955).

49. The Court thus rejected the procedures followed in Bradford Elec. Light Co. v. Clapper, 286 U.S. 145 (1932) (interests of home state and state of injury carefully examined), and Alaska Packers Ass'n v. Industrial Acc. Comm'n, 294 U.S. 532, 550 (1935) (interests of California, the forum and place of contract, found "greater" than those of Alaska).

50. In dissent, Justice Frankfurter, after reciting the facts to show that Arkansas had no particular interest in the case before the Court, remarked upon the extent to which the majority was departing from the theory of the Clapper case: "What might be regarded as the societal interest of Arkansas in the protection of the bodily safety of workers within its borders is an interest equally true of any jurisdiction where a workman is injured and exactly the sort of interest which New Hampshire had in Clapper." Carroll v. Lanza, 349 U.S. 408, 420-21 (1955).

51. 349 U.S. at 413 . 
the inference that the forum is free to apply its own conflicts rules in deciding whether an injured employee or only his compensation insurer is entitled to maintain a third-party tort action. The inference finds further support in the fact that a state's interest in determining who may assert a cause of action in its courts is perhaps an even more important and fundamental interest than one based on the possibility of a burden on the state's resources caused by inadequately compensated ${ }^{52}$ workers. ${ }^{53}$

In sum, the Constitution affords no guidance in solving the conflict-of-laws problems under consideration. Attention must turn, therefore, to nonconstitutional standards applicable in this area.

\section{Nonconstitutional Choice-Of-Law Criteria \\ Who is a Third Party?}

In some states, an injured worker may sue a "fellow employee" in a thirdparty tort action; in others, the injured worker is restricted to statutory compensation. Similarly, some states regard a general contractor as an employer of the employees of his subcontractor and thus not liable to them in tort; elsewhere, the general contractor is a third party vis-à-vis the employees of his subcontractors. Thus, in cases in which the relations of the parties have relevant contacts in two or more states, the choice of law often determines the liability of the person responsible for the plaintiff-employee's injury.

Courts have rested that choice of law on a variety of theories. Some decisions rely on the fact that the general contractor was required to insure the employees of his subcontractors under the law of the state in which the work was done and the injury occurred. ${ }^{54}$ In other cases, courts have sought to apply the law of the jurisdiction which had the most significant contacts with the tort. $^{55}$ And in still others, the traditional references to place of injury ${ }^{50}$ or

52. It is suggested here that the statutory workmen's compensation is not, by common-law and statutory wrongful-death standards, "full" compensation. Tort damages will almost invariably be greater than the statutory compensation for the same injury. Compare the compensation award with the tort judgment in Personius v. Asbury Transp. Co., 152 Ore. 286, 53 P.2d 1065 (1936), related in the text accompanying note 10 supra.

53. The right to apply local rules governing capacity to sue is certainly as important to the forum as the right to apply local statutes of limitation. The Supreme Court has recently held that the forum's application of a local statute of limitation to a cause of action based on a sister state's wrongful-death statute is not a denial of full faith and credit, although the local limitation period expired before that of the sister state. Wells v. Simonds Abrasive Co., 345 U.S. 514 (1953).

54. E.g., Jonathan Woodner Co. v. Mather, 210 F.2d 868 (D.C. Cir.), cert. denied, 348 U.S. 824 (1954).

55. See Ohlhaver v. Narron, 195 F.2d 676 (4th Cir. 1952); Stacy v. Greenbery, 9 N.J. 390, 88 A.2d 619 (1.952), rev'd on other grounds, 14 N.J. 262, 102 A.2d 48, cert. denied, 347 U.S. 988 (1954). See, generally, Morris, The Proper Law of a Tort, 64 HARv. L. REv. 881 (1951).

56. Tucker v. Texas Co., 203 F.2d 918 (5th Cir. 1953) ; Bagnel v. Springfield Sand \& Tile Co., 144 F.2d 65, 69 (1st Cir. 1944); Carroll v. Lanza, 116 F. Supp. 491 (W.D. Ark. 1953). See also Bernard v. Jennings, 209 Wis. 116, 244 N.W. 589 (1932). 
compensation ${ }^{67}$ have been regarded as the primary conflict-of-laws determinants.

Considered factually, these cases fall into two distinct groups within each of which a choice-of-law pattern is discernible. In the first group, the plaintiff's presence in the state of injury was clearly of a transient nature. For example, in Ohlhaver $v$. Narron ${ }^{\text {ss }}$ plaintiff and defendant-residents of New York and fellow employees of a New York corporation-were injured in an automobile accident in North Carolina while on a business trip for their employer. At trial, the defendant was awarded a summary judgment on the ground that, under New York law, workmen's compensation is the exclusive remedy for an employee injured in the course of his employment by the negligence of a fellow servant. In affirming the judgment for defendant, the Fourth Circuit reasoned that New York law was applicable because the plaintiff, the defendant, and their employer were New York residents, the contract of employment was made in New York, and the plaintiff's and defendant's activities were directed from that state. ${ }^{50}$ Similarly, in Stacy v. Greenberg ${ }^{60}$ the Supreme Court of New Jersey applied New York law since plaintiff and defendant, though injured in a New Jersey automobile accident, were returning to their employer in New York from a business trip to Pennsylvania. Both parties were residents of New York who had made their employment contracts there and, according to the court, had subjected themselves to the New York workmen's compensation law. The court described them as "merely ... transients en route" with a "purely casual" contact in New Jersey, and found nothing in the public policy of New Jersey that required the application of local law under those circumstances. ${ }^{61}$

In the second group of cases, the injured plaintiff has usually left his home state to work temporarily in another state-frequently on a construction project. Jonathan Woodner Co. v. Mather ${ }^{62}$ is typical. Mather, the plaintiff, resided in the District of Columbia and was employed there by a subcontractor to work on a construction project in Maryland for which the defendant, Jonathan Woodner Company, was the general contractor. The subcontractor carried compensation insurance for his employees under both the District of Columbia and the Maryland acts, and the general contractor carried insurance for the subcontractor's employees under the Maryland act. Mather, injured in Maryland through the alleged negligence of an employee of the general contractor, did not claim compensation under either statute but brought a

57. See Liberty Mut. Ins. Co. v. Goode Const. Co., 97 F. Supp. 316 (E.D. Va. 1951); Bagnel v. Springfield Sand \& Tile Co., 64 F. Supp. 768 (D. Mass. 1946), an remand from 144 F.2d 65 (1st Cir. 1944).

58. 195 F.2d 676 (4th Cir. 1952).

59. Id. at 679 .

60. 9 N.J. 390, 88 A.2d 619 (1952), rev'd on other grounds, 14 N.J. 262, 102 A.2d 48, cert. denied, 347 U.S. 988 (1954).

61. 9 N.J. at $397-98,88$ A.2d at $622-23$.

62. 210 F.2d 868 (D.C. Cir.), cert. denied, 348 U.S. $\$ 24$ (1954), 
common-law negligence action against the Jonathan Woodner Company instead. The Court of Appeals for the District of Columbia held that the law of Maryland was controlling because Maryland was the place of injury, ${ }^{03}$ and because the general contractor was required by that state to provide compensation insurance for the employees of his subcontractor. ${ }^{64}$

In dealing with similar sets of facts, the First and Fifth Circuits have made their choice of law solely on the basis of the place of injury. ${ }^{65}$ The federal court for the Western District of Arkansas has grounded its choice not only on the occurrence of the injury within the state but on "the public policy in Arkansas favoring common-law right of action for injuries to persons and property."66 At the other extreme, the federal court for the Eastern District of Virginia has attached little importance to the facts that the injury occurred within Virginia and that the general contractor was required to carry compensation insurance for the employees of his subcontractor under the law of Virginia. ${ }^{67}$ Rather, the court applied the law of the District of Columbia, which was where the plaintiff-employee ${ }^{68}$ and the subcontractor for whom he

63. Citing Bagnel v. Springfield Sand \& Tile Co., 144 F.2d 65 (1st Cir. 1944).

Although it is clear that Maryland law exempts a general contractor from tort liability to the employees of his subcontractor, that question was assumed still to be open in the District of Columbia. In Liberty Mut. Ins. Co. v. Goode Const. Co., 97 F. Supp. 316 (E.D. Va. 1951), it was assumed that the law of the District of Columbia was clear on the point and that a general contractor was not exempt from tort liability to the employees of his subcontractor.

64. 210 F.2d at 874. In making this point the court attempted to generalize from previous cases and said: "[I]n an employee-employer suit, if some workmen's compensation act purports to bar the action, that bar will be applied in the forum." Id. at 873. Although this statement is undoubtedly a fair generalization of the cases in which an employee has attempted to sue his immediate employer in tort, it is clearly erroneous as applied to cases of the kind that was before the court in Jonathan Woodner. See Carroll v. Lanza, 116 F. Supp. 491 (W.D. Ark. 1953) ; Liberty Mut. Ins. Co. v. Goode Const. Co., 97 F. Supp. 316 (E.D. Va. 1951) ; Bagnel v. Springfield Sand \& Tile Co., 64 F. Supp. 768 (D. Mass. 1946). The court's statement begs the question, for it speaks only of an "employee-employer suit," whereas in the Jonathan Woodner case the primary question was whether the defendant, a general contractor, was an "employer" of the plaintiff within the meaning of the Maryland and District of Columbia compensation acts.

65. Tucker v. Texas Co., 203 F.2d 918 (5th Cir. 1953); Bagnel v. Springfield Sand \& Tile Co., 144 F.2d 65 (1st Cir. 1944). On remand in the Bagnel case, 64 F. Supp. 768 (D. Mass. 1946), the federal district court for the District of Massachusetts held that the law of Massachusetts (the lex loci delicti) could have no application to the case because the workmen's compensation law of that state by its terms did not apply unless compensation had been paid under the Massachusetts act. Therefore, the law of New York, under which the plaintiff received compensation, was held controlling and, since the defendant general contractor was a third party under the New York law, the action was ordered to trial.

66. Carroll v. Lanza, 116 F. Supp. 491, 502 (W.D. Ark. 1953). Subsequent proceedings, which have been discussed in text accompanying note 32 supra, involved solely constitutional issues.

67. Liberty Mut. Ins. Co. v. Goode Const. Co., 97 F. Supp. 316 (E.D. Va. 1951).

68. In this case the injured employee and his compensation insurer were joint plaintiffs. 
worked resided, where the plaintiff was normally employed, and where his contract of employment was made with reference to the local workmen's compensation act. Consequently the general contractor was held not to be exempt from tort liability to the employees of his subcontractors.

It is apparent that case law establishes no clear line of decision on the choice-of-law problem involved in determining who is a third party. Practically all recent cases do indicate, however, that courts find it necessary to refer to more than simply the place of injury, contract, or trial. Although place of injury still carries great weight, the courts seem to be groping toward a "proper-law" concept in which the following factors are weighed: the transitory character of the injured employee's presence in a particular state, the place of compensation, whether the injured employee's contract specifically refers to one particular compensation act, whether the general contractor is legally required to insure the employees of his subcontractors, and whether the public policy of the forum favors expansion or restriction of employees' common-law remedies.

\section{Who is Entitled to Maintain the Third-Party Tort Action?}

The nonconstitutional choice-of-law rules applied by courts to determine whether the plaintiff may maintain a third-party tort action have focused upon the place of compensation, ${ }^{69}$ the place of injury, ${ }^{70}$ and the place of employment. ${ }^{71}$ Since none of these formulas produce desirable results in all of the varying fact situations, inquiry should be directed to the choices of law actually made in different factual contexts.

\section{Forum as the Place of Compensation but not the Place of Injury}

In cases in which the forum for the third-party action is the state where compensation was accepted or awarded but is not the state in which the compensable injury occurred, the courts, with one exception, ${ }^{22}$ have enforced the applicable subrogation provision, if any, of the local compensation act. The third party has thereby been protected from separate lawsuits by the injured employee and the insurer, and the insurer's right to reimbursement has been assured by allowing him to intervene in an employee's action, ${ }^{73}$ to continue an action commenced by the administrator of an

69. See, e.g., cases cited notes 73-75, 90, 97, and the second paragraph of note 94 infra.

70. See, e.g., cases cited notes 72,92 infra.

71. See, e.g., cases cited note 91 infra.

72. Bernard v. Jennings, 209 Wis. 116, 244 N.W. 589 (1932) ; Anderson v. Miller Scrap Iron Co., 176 Wis. 521, 182 N.W. 852 (1921), aff'd on rehearing, 176 Wis. 529, 187 N.W. 746 (1922); see text accompanying note 83 infra.

73. Carlson v. Glenn L. Martin Co., 103 F. Supp. 153 (N.D. Ohio 1952); Sloan v, Appalachian Elec. Power Co., 27 F. Supp. 108 (S.D.W. Va. 1939). 
employee's estate, ${ }^{74}$ to join with an administrator as a party plaintiff, ${ }^{75}$ to commence and maintain a tort action against the third party, ${ }^{78}$ to sue the third party on an implied contract of indemnity, ${ }^{77}$ and to sue the employee or his administrator after the employee has recovered from the third party. ${ }^{78}$

The single exception to this rule is found in the previously described Lyons and Raiche cases, ${ }^{79}$ which demonstrate the fallacies inherent in mechanically applying an over-simplified choice-of-law rule, and the necessity for deliberate characterization of the problem to be solved. Both cases arose from the same accident and were decided by the same court. Both decedents were employed on a temporary day-to-day basis, both were residents of Iowa, and the dependents of each received compensation awards under the Iowa act. Despite the overwhelming similarity in the factual situations, the court held that Lyons' administratrix could maintain a wrongful-death action against the

74. Betts v. Southern Ry., 71 F.2d 787 (4th Cir. 1934).

75. Komlos v. Compagnie Nationale Air France, 209 F.2d 436 (2d Cir. 1953), reversing 111 F. Supp. 393 (S.D.N.Y. 1952) ; Standard Oil Co. v. Lyons, 130 F.2d 965 (Sth Cir. 1942).

76. This is the effect of the decision in Raiche v. Standard Oil Co., 137 F.2d 446 (8th Cir. 1943), dismissing the action commenced by the deceased employee's administrator on the ground that the estate had no interest in the cause of action, that all of the cause of action had "passed" to the insurer under the law of Illinois. See the text following note 79 infra.

77. Travelers Ins. Co. v. Northwest Airlines, Inc., 94 F. Supp. 620 (W.D. Wis. 1950). A growing minority of courts allows the insurer to recover from the third party on quasi-contractual principles. See Riesenfeld, Contemporary Trends in Compensation for Industrial Accidents Here and Abroad, 42 CaLIF. L. Rev. 531, 568 nn.225 \& 226 (1954). By limiting the recovery to the amount of compensation paid and allowing that recovery to be set off against a judgment recovered against the third party in a tort action (see Travelers Ins. Co. v. Northwest Airlines, Inc., supra at 623), these cases are in accord with the general policy immunizing the third party from double liability. They are, however, in conflict with the frequently expressed policy that the third party should not be subjected to double suit. It may be questioned therefore whether this trend should be encouraged. See Staples v. Central Sur. \& Ins. Co., 62 F.2d 650 (10th Cir. 1932) ; Note, 35 Minn. L. Rev. 685 (1951). That at least one of the states that allow quasi-contractual recovery by the insurer (Illinois-Hyland v. $79 \mathrm{~W}$. Monroe Corp., 2 Ill. App. $2 \mathrm{~d}$ 83, 118 N.E.2d 636 (1954), Geneva Const. Co. v. Martin Transfer \& Storage Co., 351 IIl. App. 289, 114 N.E.2d 906 (1953)) is also a state that grants the insurer an exclusive right to maintain the third-party action after it has paid compensation is also noteworthy. If the insurer sues on an implied contract of indemnity rather than in tort, the injured employee would lose any chance of recovering tort damages in excess of the amount of compensation. This is, of course, but another way of stating the general criticism of giving either the insurer or the employee the exclusive right to sue; if the insurer has the exclusive right he has no economic interest in seeking any recovery in excess of the compensation benefits and the employee ought not to have to depend on the insurer's good will in obtaining the balance. If, on the other hand, the exclusive right is given to the employee, the insurer should not be dependent for reimbursement on the diligence of ill-informed, irresponsible or dishonest employees.

78. See the Anderson and Bernard cases, supra note 72. See also In the Matter of Estate of Hertell, 135 Misc. 36, 237 N.Y. Supp. 655 (Surr. Ct. 1929).

79. Text following notes 15,16 supra. 
third party but that Raiche's administratrix could not. The results turned upon a choice of law determined entirely by the place where the offer of employment was accepted. This approach has not been followed in any other case, ${ }^{80}$ and, when the issue was litigated ${ }^{81}$ three years later in Massachusetts, the court squarely held that the subrogation provisions of a workmen's compensation act could not be invoked unless compensation had actually been paid under that act.82

The Supreme Court of Wisconsin established a unique doctrine in two relatively early cases ${ }^{83}$ which have since been often distinguished but never overruled. ${ }^{84}$ In those cases, after compensation had been paid under Wisconsin law for deaths occurring in Michigan and Indiana, the administrators of the two employees commenced wrongful-death actions in Wisconsin against the third-party tortfeasors. In each case, the third party moved to dismiss on the ground that award or acceptance of compensation under the Wisconsin act subrogated the insurer to the right of action for wrongful death. These motions were denied because, the court said, the cause of action for wrongful death was created by the Michigan-or Indiana-legislature, and hence to hold that payment of compensation under the Wisconsin act vested that right of action in the compensation insurer is, in effect, to hold that the Wisconsin legislature has extra-territorial power to modify the statutes of other legislatures. Plainly, the court concluded, Wisconsin has no such power. The fallacies in this reasoning have been explored many times and need not be set forth here. ${ }^{85}$

80. See, e.g., Bagnel v. Springfield Sand \& Tile Co., 144 F.2d 65, 71-72 (1st Cir. 1944).

81. This question was not actually litigated in the Raiche case, for neither court nor counsel seemed to perceive any issue other than a determination of the factual elements involved in fixing the place of contracting. There is no indication that the question had been the subject of briefs or argument.

82. Bagne1 v. Springfield Sand \& Tile Co., 64 F. Supp. 768 (D. Mass. 1946), on remand from $144 \mathrm{~F} .2 \mathrm{~d} 65$ (1st Cir. 1944).

83. Bernard v. Jennings, 209 Wis. 116, 244 N.W. 589 (1932) ; Anderson v. Miller Scrap Iron Co., 176 Wis. 521, 182 N.W. 852 (1921), aff'd on rehearing, 176 Wis. 529, 187 N.W. 746 (1922).

S4. See Carlson v. Glenn L. Martin Co., 103 F. Supp. 153, 155 (N.D. Ohio 1952); Breitwieser v. State, 62 N.W.2d 900, 905-06 (N.D. 1954) ; City of Milwaukee v. Boynton Cab Co., 201 Wis. 581, 589-92, 231 N.W. 597, 597-98 (1930). See also Hughes v. Fetter, 257 Wis. 35, 42 N.W.2d 452, 454 (1950), rev'd, 341 U.S. 609 (1951). It has been suggested that the quasi-contractual recovery allowed the insurer against the third party in Travelers Ins. Co. v. Northwest Airlines, Inc., 94 F. Supp. 620, 622-23 (W.D. Wis. 1950); see note 77 supra, may also be traceable to the restrictive rule established by the Wisconsin court in the cases cited in the preceding note. See Riesenfeld stpra note 77, at 576 n.251.

85. See Mr. Justice Traynor, writing for the court, in Emery v. Emery, 45 Cal. 2d 421, 289 P.2d 218 (1955), and Professor Ehrenzweig's comment thereon, Parental Imminity in the Conflict of Laws: Law and Reason Versus the Restatement, $23 \mathrm{U}$. CHI. L. Rev. 474 (1956). See also Ford, Interspousal Liability for Automobile Accidents in the Conflict of Lazes: Law and Reason Versus the Restatement, 15 U. PITT. L. REv. 397, $103 \mathrm{nn} .21$ \& 22 (1954), and materials there cited. 
The Wisconsin court stated an alternative ground for its holding which, however, does require comment. It said that the acceptance of compensation by the employee's dependents could not effect an assignment to the insurer because the dependents did not own the cause of action for wrongful death; and that, under the Michigan statute, for instance, the cause of action belongs to the employee's estate and can be asserted only by the administrator of that estate. This result fails to give adequate consideration to the insurer's interest in reimbursement. Although the court said by way of dictum that the insurer has a right-presumably on quasi-contractual grounds ${ }^{86}$ - to reimbursement from the proceeds of the administrator's tort suit, this remedy requires two actions to accomplish what could be done in one and makes the insurer's interest in reimbursement entirely dependent upon the employee's or administrator's diligence and effectiveness in asserting the third-party claim. As the very existence of the subrogation provisions suggests, compensation insurers have found the employee's diligence and effectiveness lacking. ${ }^{8 t}$

An employee's "dependents" under a workmen's compensation act will often differ slightly from those who may recover for his wrongful death, but this difference need not prevent subrogation. It need affect only the distribution of the proceeds of the compensation award and the proceeds of the judgment in the wrongful-death action, with subrogation limited to the "compensation-dependents" share in the proceeds of the wrongful-death suit. $\$ s$ The administrator does not "own" the cause of action for wrongful death in any real sense, and his standing as plaintiff, as well as the subrogated insurer's, is a procedural question that should be governed by the law of the forum. ${ }^{89}$

\section{Forum as the Place of Injury but not the Place of Compensation}

In by far the largest number of cases involving a third-party tort action commenced in the state of injury the courts have chosen the law of the state under which compensation was paid ${ }^{90}$ to determine entitlement to sue. A few

86. See note 77 supra.

87. Breitwieser v. State, 62 N.W.2d 900 (N.D. 1954). See also In the Matter of Estate of Hertell, 135 Misc. 36, 237 N.Y. Supp. 655 (Surr. Ct. 1929).

88. See Riesenfeld \& Maxweli, Modern Social Legrslation 429-30 (1950).

89. The undesirability of applying any other rule is well illustrated by Komlos v. Compagnie Nationale Air France, 209 F.2d 436, 439-40 (2d Cir. 1953).

90. Kelley v. Summers, 210 F.2d 665 (10th Cir. 1954); Liberty Mut. Ins. Co. v. Goode Const. Co., 97 F. Supp. 316 (E.D. Va. 1951) ; Hebia v. Select Lake City Theater Operating Co., 11 F.R.D. 113 (N.D. Ill. 1950) ; Koepp v. Northwest Freight Lines, 10 F.R.D. 524 (D. Minn. 1950) ; Magee v. McNany, 10 F.R.D. 5 (W.D. Pa. 1950) ; Maryland to Use of Carson v. Acme Poultry Corp., 9 F.R.D. 687 (D. Del. 1949) ; Alexander v. Creel, 54 F. Supp. 652 (E.D. Mich. 1944) ; Sloan v. Appalachian Elec. Power Co., 27 F. Supp. 108 (S.D.W. Va. 1939) ; Biddy v. Blue Bird Air Serv., 374 I11. 506, 30 N.E.2d 14 (1940) ; Miller v. Yellow Cab Co., 308 Ill. App. 217, 31 N.E.2d 406 (1941); New York Cent. R.R. v. Milhiser, 231 Ind. 180, 106 N.E.2d 453 (1952) ; Employer's Liability Corp. v. Webb, 283 Ky. 115, 140 S.W.2d 825 (1940); Saloshin v. Houle, 85 
of these courts have referred to that law because it was the law of the place of the employment contract, which, by construction, incorporated the local compensation act. 01 In a minority of cases, on the other hand, standing to sue was established under the law of the forum on the ground that it was the law of the place of injury. Some of these decisions include specific references to the provisions of the compensation law of the place of injury ${ }^{92}$ others do not. ${ }^{93} \mathrm{~A}$ few suggest that the issue should be determined by the law of the forum not because it is the law of the place of injury but because the essential problem is whether the plaintiff is a real party in interest having capacity to sue. ${ }^{94}$

\section{Forum as Neither the Place of Compensation nor of Injury}

Whenever a plaintiff commences a third-party action in a jurisdiction other than that of the place of compensation or injury, he usually chooses the state of the defendant's residence. Such a choice of forum, however, has not affected the plaintiff's chances of recovery. To the contrary, in practically all of these cases judgments were rendered against the third party regardless of whether the injured employee or his compensation insurer was the plaintiff, ${ }^{95}$ and several decisions in this category emphasize a policy favoring third-party tort

N.H. 126, 155 Atl. 47 (1931) ; Privetera v. Hillcrest Homes, Inc., 29 N.J. Super. 591, 103 A.2d 55 (L. 1954); Zurich Gen. Acc. \& Liab. Ins. Co. v. Ackerman Bros., 124 N.J.L. 187, 11 A.2d 52 (Ct. Err. \& App. 1940) ; Kandelin v. Lee Moor Contracting Co., 37 N.M. 479, 24 P.2d 731 (1933); Solomon v. Call, 159 Va. 625, 166 S.E. 467 (1932); Reutenik v. Gibson Packing Co., 132 Wash. 108, 231 Pac. 773 (1924). See also Benoit v. Hathaway, 310 Mass. 362, 38 N.E.2d 329 (1941) ; Wagner v. City of Duluth, 211 Minn. 252, 330 N.W. 820 (1941).

91. See Alexander v. Creel, supra note 90; Biddy v. Blue Bird Air Serv., supra note 90; Stacy v. Greenberg, 9 N.J. 390 , \&s A.2d 619 (1952).

92. See, e.l!., Bagnel v. Springfield Sand \& Tile Co., 144 F.2d 65 (1st Cir.), cert. deried, 323 U.S. 735 (1944); Van Wie v. United States, 77 F. Supp. 22 (N.D. Lowa 1948) ; Henrikson v. Crandic Stages, 216 Iowa 643, 246 N.W. 913 (1933).

93. Jones v. Goodman, 114 F. Supp. 110 (D. Kan. 1953); Personius v. Asbury Transp. Co., 152 Ore. 286, 53 P.2d 1065 (1936) ; Rorvik v, North Pac. Lumber Co., 99 Ore. 58, 190 Pac. 331, aff'd on rehearing, 99 Ore. 82, 195 Pac. 163 (1921).

94. See Jones v. Goodman, 114 F. Supp. 110 (D. Kan. 1953); Magee v. McNany, 10 F.R.D. 5 (W.D. Pa. 1950); Maryland to Use of Carson v. Acme Poultry Corp., 9 F.R.D. 687 (D. Del. 1949) ; Reutenik v. Gibson Packing Co., 132 Wash. 108, 231 Pac. 773 (1924).

Only one case has been found in which the injury occurred, compensation was paid, and the tort action was commenced in the same state. The court assumed that the compensation act of that state was controlling on the issue of subrogation and entitlement to sue, and held that plaintiff, by accepting compensation payments for three years, without having applied for them, had made an election that resulted in subrogating the insurer to the tort cause of action against the third party. Dinardo v. Consumers Power Co., 181 F.2d 104 (6th Cir. 1950).

95. In the exceptional case, the period of limitations had expired. Hartford Acc. \& Indem. Co. v. Procter \& Gamble Co., 91 Ohio App. 573, 109 N.E.2d 287 (1952). 
liability..$^{96}$ In order to sustain the right of the particular plaintiff to maintain his action, the courts in every case looked to the act under which compensation had been paid. ${ }^{\text {g7 }}$

Whenever the statute of limitations was at issue in these cases, the courts have uniformly applied the limitations act of the forum ${ }^{98}$ while holding the law of the state of compensation determinative of when the cause of action accrued and the nature of the right asserted by the subrogated insurer. Plaintiffs have occasionally found unusual favor in the judicial implementation of these policies. Thus, a federal court in Tennessee interpreted the Texas compensation act as modifying the Texas common law and postponing the accrual of a cause of action in tort until the injured employee applied for compensation. ${ }^{90}$ The plaintiff was likewise benefited when a California insurer sued the third party in a Pennsylvania federal court to recover compensation paid a worker in California for injuries caused in California by the negligence of defendant's employee. The court held that, for statute of limitations purposes, the cause of action asserted by the insurer was one for injury to property. ${ }^{100}$ Accordingly, Pennsylvania's six-year limit for property damage was allowed.

96. E.g., American Mut. Liab. Ins. Co. v. United States Elec. Tool Co., 55 Ohio App. 107, 9 N.E.2d 157 (1936).

97. See, Carlson v. Glenn L. Martin Co., 103 F. Supp. 153 (N.D. Ohio 1952) ; State Compensation Ins. Fund v. Proctor \& Schwartz, Inc., 102 F. Supp. 451 (E.D. Pa. 1952) ; Hungate v. Hudson, 169 S.W.2d 682 (Mo. 1943) ; Scott v. Missouri Pac. R.R., 333 Mo. 374, 62 S.W.2d 834 (1933); Hartford Acc. \& Indem. Co. v. Chartrand, 239 N.Y. 36, 145 N.E. 274 (1924); American Mut. Liab. Ins. Co. v. United States Elec. Tool Co., 55 Ohio App. 107, 9 N.E.2d 157 (1936).

98. See Hutto v. Benson, 110 F. Supp. 355 (E.D. Tenn. 1953), aff'd, 212 F.2d 349 (6th Cir. 1954). On the choice of law in period of limitations problems, see STumberg, CONFLICI of LAws 147-52 (2d ed. 1951); Comment, The Statute of Limitations and the Conflict of Lazes, 28 YALE L.J. 492 (1919).

99. Hutto v. Benson, supra note 98 . The reasoning of the court suggests several unanswered questions. How long can the employee postpone accrual of the tort cause of action by delaying his application for compensation? If the injury is compensable under the law of another state and the employee applies for compensation in that state and not in Texas, when does the cause of action for the Texas tort accrue? If the employee decides not to apply for compensation but to rely entirely on his tort remedies, when does the period of limitations begin to run? Can this date be discovered only by hindsight?

100. State Compensation Ins. Fund v. Proctor \& Schwartz, Inc., 102 F. Supp. 451 (E.D. Pa. 1952). However, compare the California cases on which the court relied for this proposition (Morris v. Standard Oil Co., 200 Cal. 210, 252 Pac. 605 (1926); City of Los Angeles v. Howard, 80 Cal. App. 2d 728, 182 P.2d 278 (Dist. Ct. App. 1947)) with Aetna Cas. Co. v. Pacific Gas \& Elec. Co., 41 Cal. 2d 785, 787, 264 P.2d 5, 6 (1953), in which it was said:

The employee's general damage claim, whether prosecuted by the employee personally or by his employer or its insurance carrier on his behalf, is solely one in tort for personal injuries arising out of the negligence of the third party tortfeasor; hence the cause of action accrues at the time of the negligent act. No matter who may be the party plaintiff, the cause of action is within the express terms of [the statute of limitations for personal injuries (1 year)]. 
The results in the foregoing cases place an undue burden on third-party defendants. They are subjected to possible lawsuits for much longer periods than other tortfeasors merely because the victims of their negligence are employees with compensable injuries. These adventitious factors are unsatisfactory grounds for nullifying the policy underlying the relatively short period of limitations for personal injury actions. Moreover, the holding in those cases conflicts with the majority rule on the nature of the insurer's right as formulated in, for example, Maryland Casualty Co. v. Paton. ${ }^{101}$ There, an insurer sued a third party to recover compensation paid under the California act for a wrongful death which had occurred in Oregon. In dismissing the suit, the court rejected the plaintiff-insurer's contentions that its cause of action was separate and distinct from the action for wrongful death, and that the period of limitations on its cause of action did not begin to run until it had paid compensation to the deceased employee's dependents. ${ }^{102}$ This holding is, of course, consistent with the view that the insurer's right to sue third parties places him in the same position as the compensated employee and accords him no more than the capacity to assert the employee's cause of action. ${ }^{103}$

\section{Cases in Which no Compensation Award was Made before the Tort Action Commenced}

In a few instances, employees have suffered compensable injuries and begun third-party tort actions before receiving either compensation or an award. Without exception, the question of the choice of law to determine entitlement to sue was resolved solely by reference to the tort law of the place of injury, not to the third-party provisions of that jurisdiction's workmen's compensation act. ${ }^{104}$ Indeed, in one case, the injured employee was permitted to

101. 194 F.2d 765 (9th Cir. 1952), 37 MrNN. L. Rev. 77.

102. The plaintiff relied on the same California cases that were cited by the court in the State Compensation Insurance Fund case, supra note 100.

103. See Hartford Acc. \& Indem. Co. v. Procter \& Gamble Co., 91 Ohio App. 573, 575-76, 109 N.E.2d 287, 289 (1952).

This construction accords with the nature of subrogation and with the recent decision of the California Supreme Court construing the statutory provisions at issue in the two foregoing cases discussed in text. See Aetna Cas. \& Sur. Co. v. Pacific Gas \& Elec. Co., 41 Cal. 2d 785, 264 P.2d 5 (1953).

104. See Hynes v. Indian Trails, Inc., 181 F.2d 668 (7th Cir. 1950) ; Foster v. Denny Motor Transfer Co., 100 F.2d 658 (7th Cir. 1938) ; Rorvik v. North Pac. Lumber Co., 99 Ore. 58, 190 Pac. 331 (1920), aff'd on rehearing, 99 Ore. 82, 195 Pac. 163 (1921) (widow of the employee had made an application for an award before she sued the third party, but the award had not become final; the Oregon court indicated, however, that the presence or absence of a final award could not affect the result). But cf. Jewtraw v. Hartford Acc. \& Indem. Co., 280 App. Div. 150, 153-54, 112 N.Y.S.2d 727, 731 (1952).

Cf. Travelers Ins. Co. v. Central R.R., 143 Misc. 589, 258 N.Y. Supp. 35 (Sup. Ct. 1932) ; Employers' Liab. Assur. Corp. v. Eaby, 111 Pa. Super. 589, 170 Atl. 352 (1934), both of which reflect the rule stated in text and hold that the insurer has no subrogation rights against the third party unless it has paid compensation to the employee. 
maintain the third-party action in the courts of the place of injury despite the fact that the local compensation act would have barred him from doing so had he previously accepted compensation. ${ }^{105}$

\section{The Trend in the Courts}

Of the courts which have considered the problem, a sizable majority ${ }^{108}$ have concluded that the question of entitlement to sue in third-party tort cases should be resolved according to the provisions of the act under which compensation was paid. A number of these cases were decided at a time when many compensation acts provided that acceptance of compensation by an injured employee terminated his interest in any tort cause of action against a third party. ${ }^{107}$ Courts' inquiries about entitlement to sue naturally ended with the discovery that the employee had no interest in the cause of action. Such provisions no longer exist, ${ }^{108}$ however. Compensation acts now commonly provide for subrogation only to the extent of the compensation paid, and the employee is entitled to all tort damages recoverable in excess of that amount. Nonetheless, present statutes do not deal effectively with the conflict-of-laws problems involved in tort and wrongful-death actions against third parties. For example, no guidance is given for choosing among the states' conflicting requirements as to who may initiate a wrongful-death action. ${ }^{100}$ Moreover, no procedure exists for assuring a legally enforceable remedy both to the employee and to his insurer in conflicts cases.

The courts are therefore free to adopt the conflicts rules that best effectuate the purposes of the third-party provisions in workmen's compensation statutes. A minority of courts are developing such rules. ${ }^{110}$ These courts look to the law of the state under which compensation has been paid only for the purpose of determining whether the plaintiff is a real party in interest. If he is, the question of entitlement to sue is resolved by the law of the forum. ${ }^{111}$ This practice is consistent with accepted choice-of-law rules applicable to problems of capacity to sue. .12 $^{2}$ It also enables courts to achieve the basic policy objectives of the third-party provisions: to prevent the defendant from avoiding

105. Hynes v. Indian Trails, Inc., 181 F.2d 668 (7th Cir. 1950).

106. The fact that there is a numerical majority should not be considered overiy significant, for many of the early cases included in the majority were based upon a general legislative policy that since has been changed in many states.

107. See, e.g., the Michigan statute relied on by the court in Biddy v. Blue Bird Air Serv., 374 IIl. 506, 30 N.E.2d 14 (1940), and the Idaho statute relied upon by the defendant in Personius v. Asbury Transp. Co., 152 Ore. 286, 53 P.2d 1065 (1936).

108. See Riesenfeld, Contemporary Trends in Compensation For Industrial Accidents Here and Abroad, 42 CALIF. L. REv. 531, 569-570 (1954).

109. See notes $20-28$ supra and accompanying text.

110. See text accompanying notes 69-103 supra passim.

111. See cases cited notes 92-94 supra.

112. See Ehrenzweig, supra note 85; Ford, supra note 85, at 423-26. But cf. CHEshire, Private International Law 651-54 (4th ed. 1952). See also Goodrich, Conflict of Laws $\$ 82$ (3d ed. 1949); RestateMent, Conflict of Laws $\$ 58 \$$ (1934). 
liability, to avert the unjust enrichment of the employee, to protect the insurer's rightful expectation of reimbursement, and to safeguard the defendant's interest in avoiding a multiplicity of suits. Additionally, the courts are not required to administer a sister state's case law and the third-party provisions of its compensation act, ${ }^{113}$ but can resolve the entitlement-to-sue problem by concepts with which they are more familiar. ${ }^{114}$

\section{CONCLUSION}

In recent years, most states have either abandoned or greatly modified the cumbersome and inequitable election requirements of earlier third-party provisions; an injured employee may now recover both compensation from his employer and a tort award from the third-party tortfeasor, subject only to the compensation insurer's right of reimbursement. At the same time, many states have adopted provisions designed to protect the rights of both employee and insurer in a claim against the third party, and to enable either or both to enforce that claim. ${ }^{115}$ In conflicts cases, changes of equal importance have taken place. Decisions based upon a mechanical application of textbook formulas are now rare. In cases involving a choice of law to determine whether or not the defendant is a third party, the courts more and more are weighing and balancing a broad variety of factors to choose the applicable law. Increasingly, decisions involving a choice of law for determining whether the plaintiff is a proper party to maintain the third-party suit tend to soften the rigid procedural provisions which remain a part of some workmen's compensation acts. Dismissals on the ground that the plaintiff is not a proper party to bring the action are becoming less and less frequent; and the courts are usually successful in choosing a law which, when coupled with appropriate procedural devices, adequately protects the legitimate interests of the three parties principally concerned.

113. Cf. the mechanical jurisprudence in Hebia v. Select Lake City Theatre Operating Co., 11 F.R.D. 113 (N.D. IIl. 1950).

114. That this is of more than incidental importance is indicated by Cardozo's oftquoted remark that conflict of laws is "one of the most baffling subjects of legal science . . . Cardozo, The Paradoxes of Legal Sctence 67 (1928). See also ProsSER, Selected Topics on the Law of ToRTs 89 (1953): "The realm of the conflict of laws is a dismal swamp, filled with quaking quagmires, and inhabited by learned but eccentric professors who theorize about mysterious matters in a strange and incomprehensible jargon. The ordinary court, or lawyer, is quite lost when engulfed and entangled in it."

115. See Riesenfeld, supra note 108 , at 569 . 


\section{THE YALE LAW JOURNAL}

VOLUME 68

\section{Vovore 68}

NOVEMBER 1958

NUMBER 1

\section{BURT W. GRIFFIN \\ Michafu J. Nassau \\ Conment Editors}

Matthew T. Adanis

David ALBENDA

Alan Appelbaum

ROBERT L. BARD

ARTHUR J. Berk

Norman A. Bikales

Benjamin W. Boley

Richard A. Brady

Peter D. Caldwell

JAMES M. EDWARDS

Eliezer Ereli

David R. Evans

ThOMAS N. FroHoCK

DAVID GoldBerg

Stuart B. Goldman

\section{Sydney M. Cone, III}

Editor-in-Chief

RoBert J. ENGELMLAN
Article and Book
Review Editor

Mitchen J. EzER

Managing Editor

RICHARD S. HARRISON

NeIL S. HeCHT

Reuben L. HedLund

JACOB W. HeLLER

Alan M. Hoffman

Benjamin T. Hopkins, II

William A. Kass

ARON Katz

N. Herschel Koblenz

EUGENE I. LANBERT

J. D. LAMBERT

IRVING I. LESNICK

JoHN C. MCGuire

FREDERICK W. MCNABB, JR.

JoHN K. MCNuLTY
JEROLD H. ISRAER

ALAN L. Wurtzes.

Note Editors

\author{
Stephen MANN \\ Bruce Montgonery \\ JerRoLd L. MorgUtAS \\ Sansuel Myers \\ J. Alexander Onderdonk \\ Alan D. Pekerner \\ Chardes J. Prentiss \\ Herbert Schreirer \\ Barky Simman \\ Richard Lauder Sutton \\ Colin C. TAIT \\ Grlbert Paul Verbit \\ HERBERT S. WANDER \\ DONALD P. WEFER \\ T. Cecil Wray, JR.
}

MARIE MCMAHON

Business Secretary

The YaLe LAW Journal mourns the death of WALTON HALE HAMILTON

Southmayd Professor Emeritus of Law, Yale Law School

\section{CONTRIBUTORS TO THIS ISSUE}

Janes WM. Moore. Sterling Professor of Law, Yale University; J.D. 1933, University of Chicago; J.S.D. 1935, Yale University. Member, 1953-1956, U. S. Supreme Court's Advisory Committee on Federal Rules of Civil Procedure. Special Consultant to the Committee on Revision of the Laws of the House of Representatives, on revision of the Judicial Code. Co-reporter, in 1937, to the International Academy of Comparative Law, the Hague, on liquidation and reorganization legislation in England, Canada and the United States. Author of numerous works on bankruptcy and federal procedure.

ALAN W. Ford. LL.B. 1951, J.S.D. 1954, University of California. Formerly, Assistant to the Legal Adviser, Department of State. Presently with the firm of Chase, Rotchford, Downen \& Drukker, Los Angeles, California. 